\title{
Sosialisasi Computational Thingking Pada Guru MTs Yayasan NW Darul Abror Gunung Rajak Lombok Barat
}

\author{
Rifqi Hammad ${ }^{l)}$, Kurniadin Abd Latif ${ }^{2}$, Kartarina ${ }^{3)}$, Pahrul Irfan ${ }^{4)}$, Moch Syahrir ${ }^{5)}$, \\ Andi Sofyan Anas ${ }^{6)}$, Ayu Cahyablindar ${ }^{7}$, M. Hidayatullah ${ }^{81}$ \\ ${ }^{122(3) 4 / 5)(6) 788}$ Universitas Bumigora, Mataram, Indonesia
}

Corresponding Author: Rifqi Hammad, rifqi.hammad@universitasbumigora.ac.id

\begin{abstract}
Abstrak: Computational thinking merupakan kemampuan intelektual yang digunakan dalam menyusun permasalahan serta solusinya, sehingga solusi yang diberikan dapat digunakan secara efektif oleh agen pemroses informasi baik itu manusia maupun komputer. Pengabdian ini dilakukan dengan tujuan untuk memperkenalkan konsep Computational thingking dan penerapannya di mata pelajaran. Sosialisasi dan pelatihan ini diberikan kepada guru-guru MTs Yayasan NW Darul Abror Gunung Rajak dengan jumlah peserta kurang lebih 52 orang. Pengabdian ini dilaksanakan menjadi 2 sesi yaitu sesi sosialisasi dan evaluasi. Pada bagian sosialisasi guru-guru diberikan materi tentang gambaran, manfaat dan pentingnya computational thinking untuk diterapkan sejak dini. Pada sesi sosialisasi ini juga para guru juga diberikan materi terkait penerapan computational thinking di berbagai macam mata pelajaran seperti matematika, IPA, IPS dan Bahasa. Pada sesi evaluasi, para guru diberikan beberapa pertanyaan untuk mengetahui sejauh mana para guru memahami konsep Computational thinking dan penerapannya dalam mata pelajaran. Berdasarkan hasil evaluasi, didapatkan bawah para guru sudah cukup memahami konsep Computational thinking dan penerapannya di mata pelajaran. Hal ini terlihat pada hasil evaluasi dari kegiatan yang telah dilakukan kepada para guru. Para guru mampu menjawab tentang computational thinking dan dapat membuat contoh penerapan computational thinking pada matapelajaran yang diajarkannya.
\end{abstract}

Kata Kunci: Sosialisasi, Computational Thinking, MTs Yayasan NW Darul Abror, Mata Pelajaran.

Abstract: Computational thinking is an intellectual ability that is used in formulating problems and solutions, so that the solutions provided can be used effectively by information processing agents, both humans and computers. This service was carried out with the aim of introducing the concept of computational thingking and its application in the subject. This socialization and training was given to MTs Yayasan NW Darul Abror Gunung Rajak teachers with approximately 52 participants. This service was carried out into 2 sessions, namely socialization and evaluation sessions. In the socialization section, the teachers were given material about the description, benefits and importance of computational thinking to be applied from an early age. During this socialization session, the teachers were also given material related to the application of computational thinking in various subjects such as mathematics, science, social studies and language. In the evaluation session, the teachers were asked several questions to find out the extent to which the teachers understood the concept of computational thinking and its application in the subject. Based on the results of the evaluation, it was found that the teachers had sufficiently understood the concept of computational thinking and its application in subjects. This can be seen in the results of the evaluation of the activities that have been carried out to the teachers. The teachers are able to answer about computational thinking and can make examples of the application of computational thinking in the subjects they teach.

Keywords: Socialization, Computational Thinking, MTs Yayasan NW Darul Abror, Subject.

Submitted: 26.01.2021, Revised: 05.04.2021, Accepted: 09.04.2021 


\section{Pendahuluan}

Di era globalisasi saat ini, teknologi digital memiliki peranan penting dalam kehidupan sehari-hari. Dengan adanya peningkatan permintaan untuk bersaing pada ekonomi global, negara-negara perlu mempersiapkan siswa dengan dengan pengetahuan teknis yang sesuai dengan keterampilan komunikasi yang bersaing (Tsai \& Tsai, 2017). Penggabungan teknologi dan pengetahuan merupakan solusi dan sudah menjadi trend saat ini (Maharani et al., 2019). Menurut (Malik, 2017) salah satu keterampilan yang dapat digunakan untuk menggabungkangn teknologi dengan pengetahuan adalah dengan berfikir komputasi (Computational Thinking)

Computational thinking merupakan suatu keterampilan pemecahan masalah yang menggabungkan pengetahuan komputasi (Jamil, 2017). Computational thinking adalah kemampuan intelektual yang digunakan dalam menyusun permasalahan serta solusinya, sehingga solusi yang diberikan dapat digunakan secara efektif oleh agen pemroses informasi baik itu manusia maupun komputer (Wing, 2006). Computational thinking memiliki beberapa komponen yaitu abstaksi, pengenalan pola, generalisasi, algoritma dan debugging (Maharani et al., 2019). Abstraksi merupakan komponen dalam computational thinking yang mampu mendefinisikan masalah dalam konteks pemecahan masalah. Setelah permasalahan ditemukan kemudian dilakukan pencarian terhadap pola yang ada pada permasalahan tersebut. Penemuan pola tersebut dapat dimanfaatkan untuk membuat generalisasi dari permsalahan yang dihadapi. Pada saat melakukan proses pemecahan masalah perlu dilakukan berdasarkan langkah-langkah yang terstuktur (Algoritma). Pada saat permasalahaan dan solusinya dilakukan, tahap berikutnya merupakan debugging yang merupakan tahap untuk melakukan evaluasi pada solusi yang diberikan dengan melakukan penelusuran kembali setiap langkah dari solusi yang diberikan (Tang et al., 2020). Namun menurut pendapat lain, komponen dari computational thinking adalah dekomposisi, pengenalan pola, abstraksi dan algorithma (Marieska et al., 2019).

MTs Yayasan NW Darul Abror Gunung Rajak merupakan salah satu madrasah tsanawiyah yang berada di kecamatan sakra. MTs NW Darul Abror adalah lembaga pendidikan tingkat menengah pertama beridiri pada tanggal 1 Juli 1985. Kegiatan belajar dan mengajar yang ada pada sekolah tersebut saat ini masih belum menerapkan konsep computational thinking hal ini dapat dilihat dari kegiatan belajar yang berlangsung saat ini masih dengan metode menghafal dan belum menyisipkan kemampuan problem solving dengan langkah-langkah seperti yang ditunjukkan pada computational thinking. Sedangkan saat ini kemampuan problem solving sangat dibutuhkan sebagai modal untuk anak-anak Indonesia agar dapat bersaing di bursa kerja global (Sukamto et al., 2019).

Bebras merupakan sebuah komunitas yang terdiri dari berbagai praktisi dan universitas di Indonesia yang bertujuan untuk mengenalkan dan mempromosikan computational thinking kepada guru dan murid di berbagai kalangan mulai dari guru dan murid kelas 3 SD sampai masyarakat luas (BebrasIndonesia, 2018). Bebras bekerja sama dengan berbagai universitas dalam mengenalkan computational thinking, salah satunya adalah universitas bumigora yang disebut sebagai Biro Universitas Bumigora. Biro Bebras Universiata Bumigora terdiri dari beberapa dosen aktif. Bebras mengenalkan dan mengajarkan tentang berpikir komputasi dengan berbagai contoh permasalahan yang disebut dengan tantangan bebras. Tantangan tersebut menyajikan berbagai jenis soal yang dapat mendorong siswa untuk berfikir kreatif dan kritis dalam menyelesaikan persolan dengan menerapkan konsep computational thinking (Rosadi et al., 2020).

Berdasarkan masalah tersebut, perlu dilakukan sosialisasi computational thinking pada guru-guru MTs Yayasan NW Darul Abror sebagai bentuk pengabdian dosen masyarakat. 
Kegiatan pengabdian tersebut bertujuan untuk memperkenalkan konsep computational thinking dan penerapannya dalam mata pelajaran kepada guru-guru MTs Yayasan NW Darul Abror. Sehingga para guru tersebut dapat menyisipkan materi computational thinking pada materi yang diampunya. Penerapan computational thinking ini berujuan untuk eningkatkan kemampuan problem solving pada murid - murid MTs Yayasan NW Darul Abror dalam menghadapi trend yang sedang berjalan saat ini dan yang akan datang. Dengan adanya sosialisasi ini diharapkan dapat meningkatkan kesadaran akan pentingnya kemampuan problem solving sejak dini. Adapun sosialisasi dan pelatihan ini diikuti oleh 52 guru dari berbagai mata pelajaran seperti matematika, IPA, IPS dan lain-lain.

\section{Metodologi}

Metode pelaksanaan yang dilakukan pada pengabdian ini terbagi menjadi beberapa tahapan. Adapun tahapan tersebut dapat dilihat pada Gambar 1.

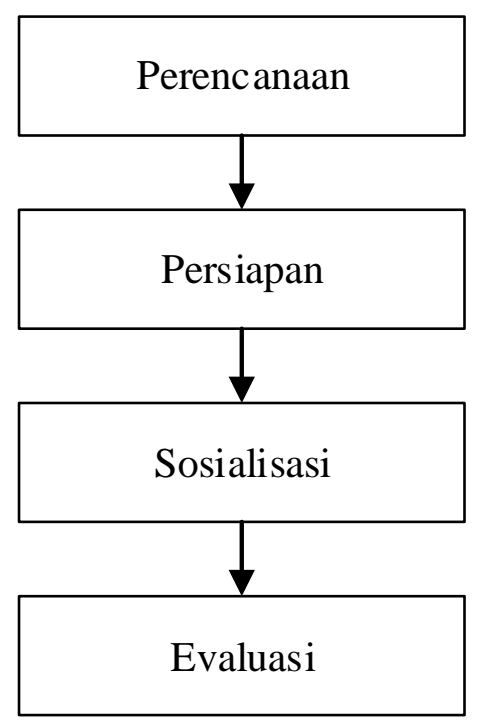

Gambar 1 Tahapan Pelaksanaan

Gambar 1 menunjukkan tahapan pelaksanaan yang dilakukan pada pengabdian ini. Pada Gambar tersebut terlihat 4 tahapan yaitu Perencanaan, Persiapan, Sosialisasi, dan Evaluasi.

\section{A. Tahap Perencanaan.}

Pada tahap ini dilakukan kerjasama dengan MTs Yayasan NW Darul Abror dengan biro bebras universitas bumigora terkait dengan kegiatan pengabdian sosilisasi computational thinking. pada tahap ini juga dirancang terkait dengan posedur dan hal lainnya terkait pelaksanaan sosialisasi.

\section{B. Tahap Persiapan.}

Tahap persiapan ini merupakan tahap dimana dilakukannya persiapan terkait hal-hal yang diperlukan selama sosialisasi dan pelatihan. Hal-hal yang dipersiapkan dapat berupa peralatan yang akan digunakan seperti komputer, alat tulis dan lain-lain. Selain peralatan, hal yang dipersiapkan juga adalah materi yang akan disajikan pada saat sosialisasi. 


\section{Tahap Sosialisasi.}

Pada tahap ini tim pengabdian menyampaikan materi yang telah disipakan pada tahap persiapan sebelumnya kepada para guru MTs Yayasan NW Darul Abror. Mulai dari pengenalan computational thinking, Pentingnya computational thinking, Implementasi computational thinking di Mata Pelajaran hingga pemberian tutorial terkait pembuatan dan penggunaan akun Olympia pada http:olympia.id yang mana pada Olympia terdapat contohcontoh soal yang dapat digunakan sebagai contoh pengimplementasian computational thinking di mata pelajaran.

\section{Tahap Evaluasi.}

Pada tahap ini dilakukan evaluasi untuk mengetahui sejauh mana pemahaman guru-guru terhadap computational thinking. Tahap ini dilakukan dengan cara diskusi dan tanya jawab.

Dari tahapan pelaksanaan yang disebutkan diatas terdapat target luaran yang diharapkan dari kegiatan pengabdian terkait sosialisasi computational thinking. Adapun target luaran yang diharapkan adalah sebagai berikut:

1. Pengenalan materi computational thinking melalui sosialisasi kepada guru guru MTs Yayasan NW Darul Abror, bertujuan untuk menambahkan pengetahuan terkait computational thinking kepada guru guru dan juga memberikan kesadaran akan pentingnya kemampuan problem solving untu dimiliki sejak dini.

2. Dengan adanya sosialisasi computational thinking yang diberikan kepada guru, hal tersebut dapat menjadi bekal untuk mendapatkan gambaran secara rinci terkait computational thinking dan penerapan computational thinking diterapkan dalam menyelesaikan suatu masalah.

Kegiatan pengabdian dilakukan pada hari sabtu 19 September 2020 bertempat di Aula MTs NW Darul Abror yang dihadiri oleh 52 Guru. Kegiatan pengabdian ini dibagi menjadi 2 yaitu sosialisasi computational thinking dan Evaluasi. Adapun rundown kegiatan pengabdian dapat dilihat pada tabel 1.

Tabel 1. Rundown Acara Kegiatan

\begin{tabular}{|c|c|c|c|}
\hline No & Pukul & Agenda & Pelaksana \\
\hline 1. & $08.30-09.00$ & Registrasi Peserta & Panitia \\
\hline 2. & $09.00-09.20$ & Pembukaan & Pihak Sekolah \\
\hline 3. & $09.20-09.50$ & Pengenalan Bebras & $\begin{array}{c}\text { Biro Bebras } \\
\text { UBG }\end{array}$ \\
\hline 4. & $09.50-10.30$ & Pengenalan CT & $\begin{array}{c}\text { Biro Bebras } \\
\text { UBG }\end{array}$ \\
\hline 5. & $10.30-11.30$ & $\begin{array}{c}\text { Penerapan CT di dalam mata } \\
\text { pelajaran }\end{array}$ & $\begin{array}{c}\text { Biro Bebras } \\
\text { UBG }\end{array}$ \\
\hline 6. & $11.30-12.00$ & Pembuatan akun Olympia.id & $\begin{array}{c}\text { Biro Bebras } \\
\text { UBG }\end{array}$ \\
\hline 7. & $12.00-12.30$ & Diskusi & $\begin{array}{c}\text { Biro Bebras } \\
\text { UBG }\end{array}$ \\
\hline 8. & $12.30-12.45$ & Kuesioner Akhir Kegiatan & Panitia \\
\hline 9. & $12.45-13.00$ & Penutupan & Panitia \\
\hline
\end{tabular}




\section{Hasil dan Pembahasan}

\section{Tahap Perencanaan}

Pada tahap ini tim pengabdian melakukan kerjasama dengan pihak MTs Yayasan NW Darul Abror mengenai kegiatan sosialisasi computational thinking. Hasil yang didapatkan dari tahap ini adalah tim pengabdian mendapatkan kesepakatan untuk bekerjasama dengan pihak MTs Yayasan NW Darul Abror untuk melakukan kegiatan sosialisasi computational thinking yang diikuti oleh guru-guru MTs Yayasan NW Darul Abror.

\section{Tahap Persiapan}

Pada tahap ini tim pengabdian melakukan persiapan terkait dengan kegiatan sosialisasi. Adapun beberapa hal yang dipersiapkan antara lain seperti tempat kegiatan sosialisasi, peralatan-peralatan kegiatan seperti komputer, kabel roll, printer, proyektor dan kabel internet dan juga materi yang akan disampaikan pada kegiatan sosialisasi.

\section{Tahap Sosialisasi}

Tahap sosialisasi ini merupakan tahap pelaksanaan kegiatan. Kegiatan pengabdian dilakukan pada tanggal 19 September 2020 di MTs Yayasan NW Darul Abror ini diikuti oleh sekitar 58 Guru. Kegiatan sosialisasi dilakuan dengan cara menyampaikan materi mengenai konsep computationl thinking, pentingnya computational thinking dan penerapannya di mata pelajaran yang dilakukan oleh tim pengabdian. Kegiatan sosialisasi berjalan dengan baik dan mendapatkan antusiasme yang cukup tinggi dari para peserta. Setiap kali terdapat materi yang kurang dipahami oleh para peserta, peserta langsung memberikan pertanya terkait materi yang kurang dipahami.

Selain penyampaian materi, para peserta juga dibantu membuat akun Olympia pada http:Olympia.id. akun tersebut dapat digunakan untuk melakukan latihan-latihan soal penerapan computational thinking di berbagai mata pelajaran. Soal soal tersebut juga memberikan gambaran kepada para peserta tentang penerapan computational thinking di mata pelajaran. Hasil dari kegiatatan sosialisasi ini adalah peserta telah memiliki pengetahuan tentang computational thinking dan penerapannya di mata pelajaran serta telah memiliki akun Olympia.

Dalam kegiatan sosialisasi computational thinking, para peserta diberikan materi terkait konsep computational thinking, manfaat dan peranannya. Salah satu contoh materinya yang disampaikan dapat dilihat pada gambar 2.

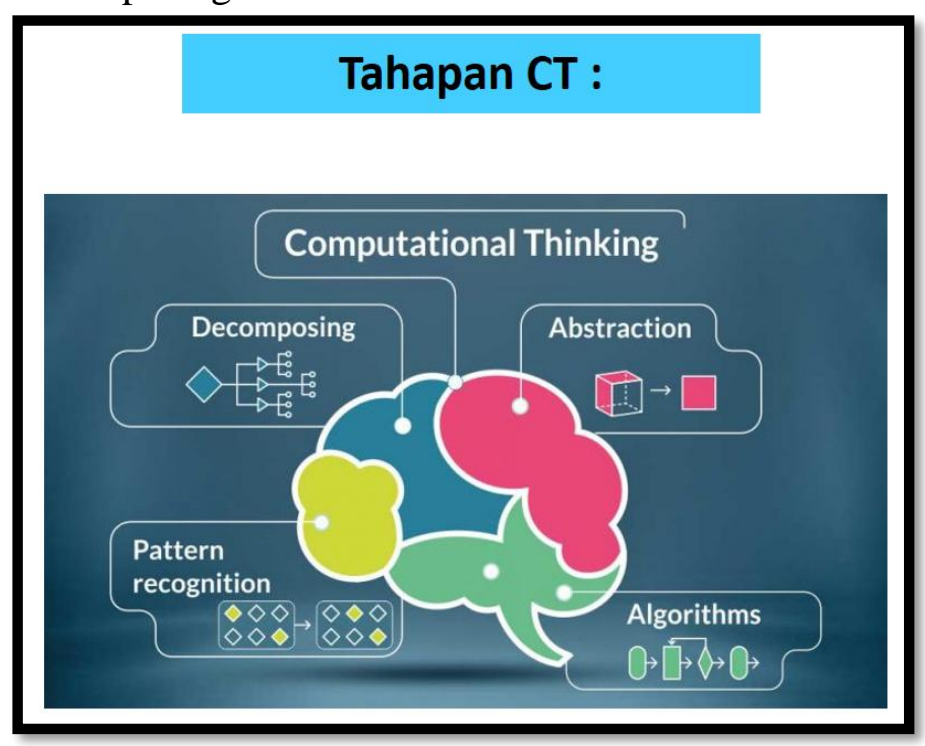

Gambar 2. Contoh Materi Sosialisasi 
Pada Gambar 2 ditunjukkan materi tentang tahapan computational thinking. pada materi tersebut terdapat 4 tahapan computational thinking yaitu:

1. Decomposition: Memecahkan suatu permasalahan yang rumit menjadi beberapa bagian yang lebih sederhana

2. Pattern Recognition: mencari kemiripan dengan berbagai permasalahan lain

3. Abstraction: Hanya berfokus kepada permasalahan utama saja dan mengabaikan informasi yang dianggap tidak relevan dengan permsalahan utama

4. Algorithm: Menyusun langkah-langkah dalam menyelesaikan permasalahan yang dihadapi.

Adapun kegiatan penyampaian materi yang dilakukan oleh tim pengabdian dapat dilihat pada Gambar 3.

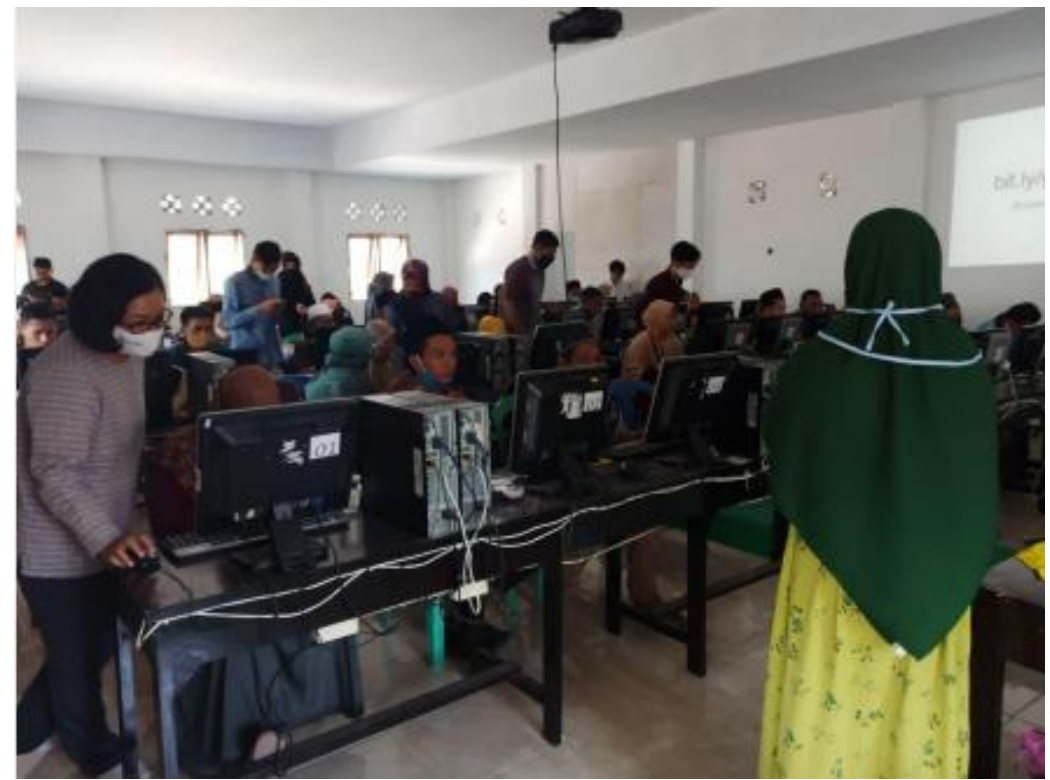

Gambar 3. Penyampaian Materi Sosisalisasi

Setelah diberikannya materi tentang konsep, manfaat serta pentingnya computational thinking, para peserta memiliki pengetahuan tentang konsep, manfaat dan pentingnya computational thinking. Kegiatan berikutnya merupakan penyampaian materi penerapan computational thinking. pemberian materi dapat dilihat pada gambar 4.

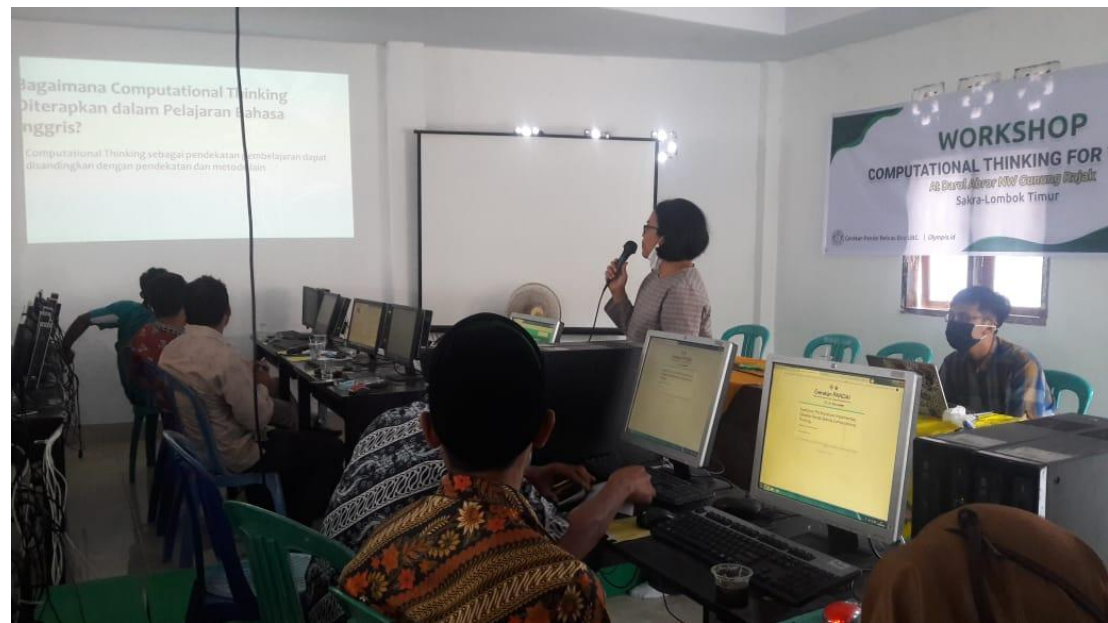

Gambar 4. Penyampaian Materi Penerapan Computational Thinking Pada Mata Pelajaran 
Pada gambar 4 ditunjukkan salah satu contoh materi penerapan computational thinking pada mata pelajaran Bahasa inggris. Pada materi tersebut para peserta diberikan contoh soal yang belum mengandung computational thinking dan yang sudah mengandung computational thinking. para peserta juga diberikan penjelasan mengenai cara menerapkan computational thinking di mata pelajaran yang diampunya. Selain Bahasa inggris para peserta diberikan juga materi penerapan computational thinking di mata pelajaran matematika, IPA dan IPS. Setelah diberikan materi penerapan ct di matapelajaran, para peserta dibantu oleh tim pengabdian untuk membuat akun Olympia pada http:Olympia.id yang mana pada akun tersebut terdapat latihan dan contoh soal penerapan computational thinking yang dapat digunakan untuk menambah pengetahuan dan pemahaman para peserta dalam menerapkan computational thinking. Adapun kegiatan tersebut ditunjukkan pada gambar 5.

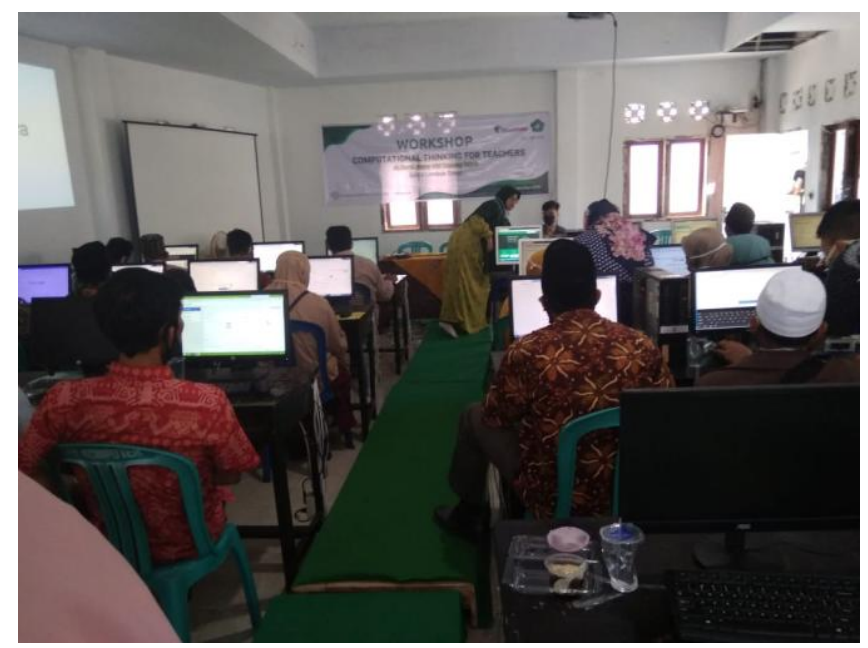

Gambar 5. Pemanduan Pembuatan Akun Olympia

Kegiatan terakhir yang dilakukan adalah evaluasi. Kegiatan evaluasi dilakukan dalam bentuk tanya jawab yang dilakukan oleh tim pengabdian dengan para peserta. Tim pengabdian mengajukan beberapa pertanyaan dan para peserta mampu menjawab pertanyaan tersebut. Melihat kemampuan menjawab para peserta maka dapat dikatakan bahwa para peserta telah memiliki pemahaman terkait computational thinking dan penerapannya di mata pelajaran. Kegiatan evaluasi dapat dilihat pada gambar 6.

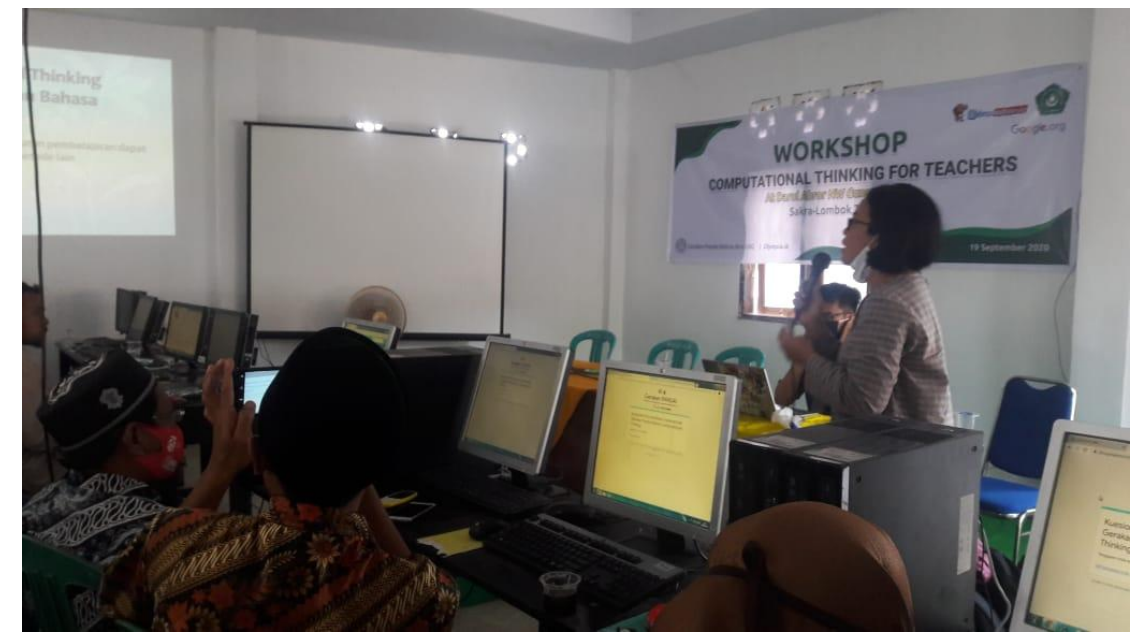

Gambar 6. Kegiatan Evaluasi Materi Sosialisasi Computational Thinking 
Setelah kegiatan evaluasi selesai kegiatan pelatihan dan sosialisasi ditutup dengan foto bersama antara tim pengabdian dengan perwakilan guru-guru MTs NW Darul Abror seperti yang ditunjukkan pada gambar 7 .

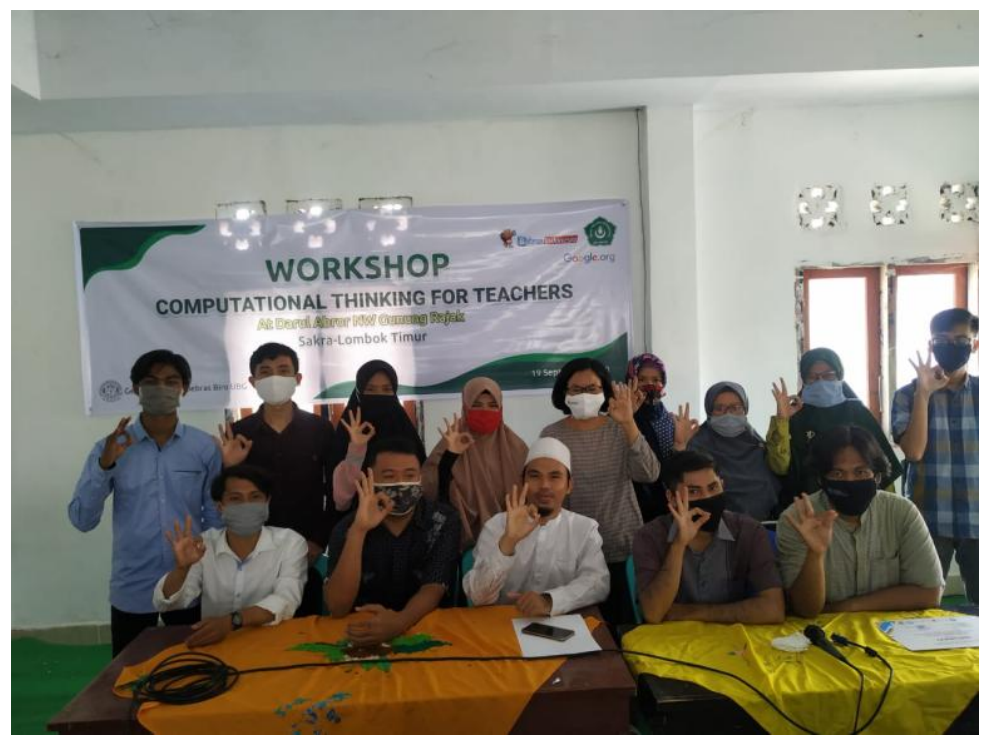

Gambar 7. Foto Bersama Tim Pengabdian dengan Perwakilan MTs NW Darul Abror

\section{Tahap Evaluasi}

Tahap evaluasi ini dilakukan setelah tahap sosialisasi. Kegiatan yang dilakukan pada tahap evaluasi ini berupa kuisioner yang digunakan untuk mengetahui pemahaman peserta terkait dengan computational thinking dan penerapannya dalam mata pelajaran. Tahap kuisioner yang dilakukan terbagi menjadi 2 yaitu pra sosialisasi dan pasca sosilisasi. Adapun grafik hasil evalusi terdapat pada gambar 2 .

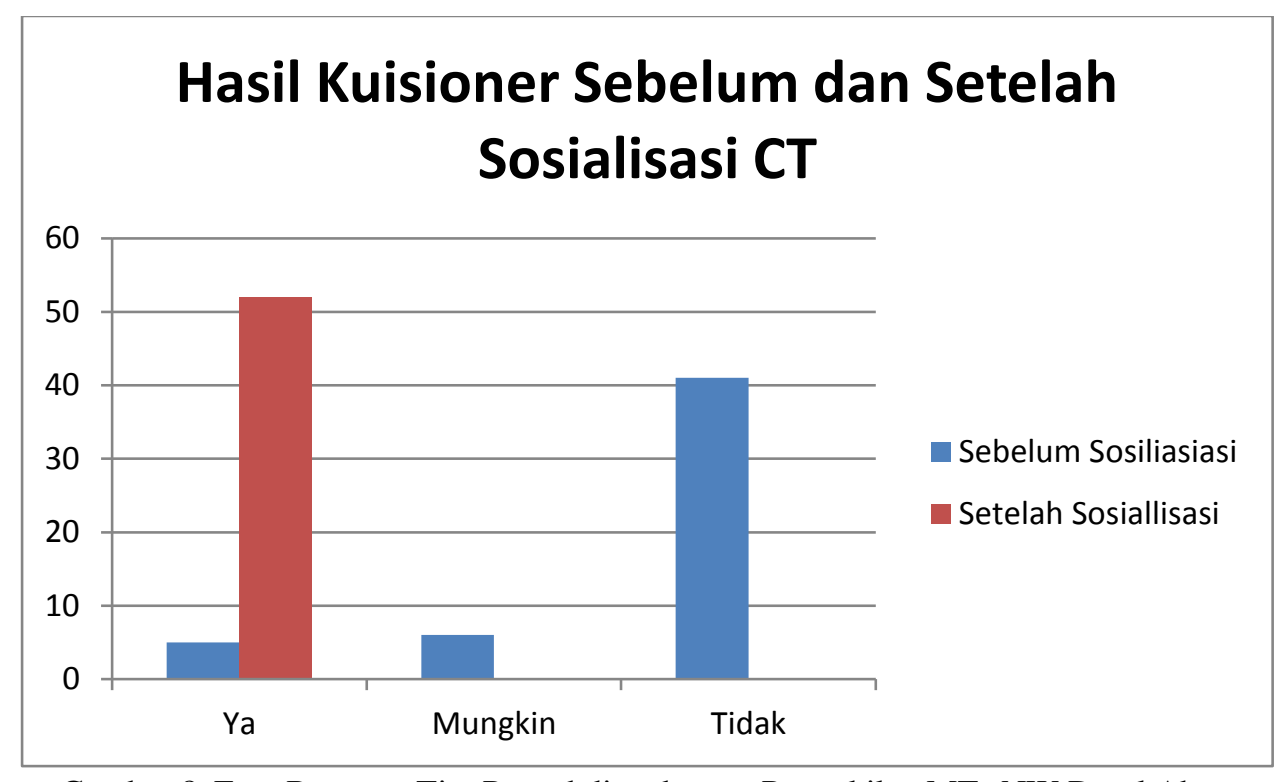

Gambar 8. Foto Bersama Tim Pengabdian dengan Perwakilan MTs NW Darul Abror

Berdasarkan grafik diatas bahwa peserta sosialisasi memahami computational thingking setelah adanya sosialisasi. Hasil dari kegiatan ini adalah hampir semua peserta telah memiliki 
pemahaman terkait computational thinking dan penerapannya. Hal ini dapat dilihat dari kemampuan menjawab peserta dari beberapa petanyaannya yang dilontarkan oleh tim pengabdian.

\section{Simpulan}

Rangakaian kegiatan pengabdiian ini dilakukan untuk mengenalkan dan melatih kemampuan Computational thinking kepada para guru MTs NW Darul Abror sehingga para guru tersebut dapat menerapkannya dalam kegiatan belajar dan mengajar. Dengan adanya penerapan computational thinking dalam kegiatan belajar dan mengajar diharapkan para murid dapat menumbuhkan dan memiliki kemampuan problem solving. Adapun hasil yang diperoleh dari kegiatan ini adalah adanya pemahaman yang dimiliki oleh para guru terkait computational thinking dan juga para guru memiliki gambaran tentang implementasi computational thinking pada Mata Pelajaran yang diajakarkannya.

\section{Ucapan Terima Kasih}

Ucapan terimakasih disampaikan kepada biro Bebras atas diberikannya kesempatan untuk bergabung dan berkontibusi pada kegiatan sosialisasi dan pelatihan computational thinking. Ucapan terimakasih juga diberikan kepada MTs NW Darul Abror selaku mitra pengabdian yang telah menyediakan waktu, dan tempat untuk pelaksanaan kegiatan ini.

\section{Daftar Pustaka}

BebrasIndonesia. (2018). Apa Itu Bebras $\square$ ? Bebras. http://bebras.or.id/v3/apa-itu-bebras/

Jamil, H. . (2017). Visual Computational Thinking Using Patch. ICWL, 10473, 208-214. https://doi.org/10.1007/978-3-319- 66733-1

Maharani, S., Kholid, M. N., Pradana, L. N., \& Nusantara, T. (2019). Problem Solving in The Context Of Computational Thinking. Infinity Journal of Mathematics Education, 8(2), $109-116$.

Malik, S. (2017). Peningkatan Kemampuan Berpikir Komputasi Siswa Melalui Multimedia Interaktif Berbasis Model Quantum Teaching and Learning. Universitas Pendidikan Indonesia.

Marieska, M. D., Rini, D. P., Oktadini, N. R., Yusliani, N., \& Yunita. (2019). Sosialisasi dan Pelatihan Computational Thinking untuk Guru TK, SD, dan SMP di Sekolah Alam Indonesia (SAI) Palembang. Prosiding Annual Research Seminar 2019 $\square$ : Computer Science and ICT, 7-10.

Rosadi, M. E., Wagino, Alamsyah, N., Rasyidan, M., Yogy, M., \& Kurniawan. (2020). Sosialisasi Computational Thinking untuk Guru-Guru di SDN Teluk Dalam 3 Banjarmasin. Jurnal SOLMA, 9(1), 45-54.

Sukamto, T. S., Pertiwi, A., Affandy, Syukur, A., Hafdhoh, N., \& Hidayat, E. Y. (2019). Pengenalan Computational Thinking Sebagai Metode Problem Solving Kepada Guru dan Siswa Sekolah di Kota Semarang. ABDIMASKU, 2(2), 99-107.

Tang, X., Yin, Y., Lin, Q., Hadad, R., \& Zhai, X. (2020). Assessing computational thinking: A systematic review of empirical studies. Computers and Education, 148(April), 103798. https://doi.org/10.1016/j.compedu.2019.103798

Tsai, M., \& Tsai, C. (2017). Applying Online Externally Facilitated Regulated Learning and 
Computational Thinking to Improve Students' Learning. Universal Accses Online Information, 17(4), 811-820.

Wing, J. M. (2006). Computational Thinking. Communications of the ACM, 49(3), 33-35. 